Digital Press Social Sciences and Humanities

The Influence of Dakwah Through Social Media Toward Student Understanding of Islam

Imamul Arifin, Ramadhan Tegar Imansyah and Achmad Bagus Okto Faerizqi

Proceeding of 9th International Conference on Nusantara Philosophy (ICNP) Arndt Graf, Fitri Alfariz, M Rodinal Khair Khasri, Rachmad Hidayat, Rokhmat Sairah, Zaid bin Ahmad (eds) 


\title{
The Influence of Dakwah Through Social Media Toward Student Understanding of Islam
}

\author{
Imamul Arifin", Ramadhan Tegar Imansyah, and Achmad Bagus Okto Faerizqi \\ Faculty of Mechatronics Engineering, Electronic Engineering Polytechnic Institute of Surabaya, Indonesia \\ *e-mail: imamul@pens.ac.id
}

\begin{abstract}
In this era of technology that continues to develop, the development is also supported by progress of the development of information and communication sectors. Social media is an important medium in making this happen. In social media, there is various content that can be watched by all people, especially students, which brings both good and bad impacts. Apart from all that, the (Religius Proselytizing) here has an opportunity to balance the development of information technology by utilizing the social media as a means of supporting dakwah. The purpose of this study was to determine the effect of dakwah content through social media on the level of student understanding of Islam. This research method uses a quantitative descriptive approach by taking a questionnaire in data collection and then analyzing it by simple linear regression analysis to determine the effect of the independent variable on the dependent variable. The result of this study is a significance value of 0.000 which is smaller than 0.05 with a simple linear regression equation $\mathrm{Y}=0.372+0.831 \mathrm{X}$. The results of the model feasibility test ( $\mathrm{F}$ test) also show the calculated $\mathrm{F}$ value of $194.005>\mathrm{F}$. From all the results obtained It was found that a conclusion can be drawn that there is an effect of dakwah content disseminated through social media toward students' understanding of Islam, as evidenced by a significance value of 0.000 which is smaller than 0.05 .
\end{abstract}

\section{Keywords}

dakwah content, social media, Islamic understanding, student

\section{Introduction}

Human life today is growing with the existence of technology. In this era, we already know, and it becomes a fact that life of human being need a variety of information(Alamsyah A, 2018). Many things are getting easier and faster to access nowadays because of the sophistication of technology. These sophistications make it easier for human life in all their daily activities. Many impacts arise because of technology, both positive and negative directions. It all depends on the individual who accepts and uses technology. The impact brought by this technology is more positive because it brings some good influences, especially in the world of information.

In today's world of information, many things are made easier because of the fast and instant process of getting information. This sophistication is supported by the emergence of applications or platforms that are provided to support the process of digitizing this information. Many applications or platforms have been used by many audiences to access and provide a lot of information in a short time. This platform is facilitated with several features that contain content that will later be seen and consumed by all circles of society.

Thus, emerging content will later fulfil and fill the application. Social media has developed very significantly from year to year (Cahyono A, 2016). Social media contents can be created by anyone in all corners of the world. As we can see now a lot of content, especially Islamic ones, are starting to be echoed through social media. Social media presents a big challenge in the field of da'wah, especially for the (Religius Proselytizing) (Nikmah F, 2020). Yet many preachers are starting to look at the social media as a 
means of supporting these preachers in carrying out dakwah and replacing the ways of preaching in previous times. In addition, with the existence of social media, the da'wah content will be easier to access in a short process and directly through each person's device. Especially during this covid-19 pandemic, many students access social media to spend some of their time at home. With the use of advances in digital technology, and social media both in form of communication and information so that it can be used as an option by the preacher in Islam preaching during a pandemic (Parhan et al., 2021). With social media, da'wah is still carried out even though it is not in public places and mosques, with social media it is possible to preach throughout Indonesia and even the world (Putra, 2021).

Along the way, we cannot deny that many people, especially students, who are teenagers, prefer to access non-Islamic content because they feel boring and are often indifferent in understanding more about their religious teachings. Therefore, we often encounter many students who still lack understanding of their religion, especially Islam here. The role or contribution of students in studying their religion, especially Islam, is very much needed this time.

There is a problem that is mushrooming nowadays among students and it is clearly illustrated that this student, who is a teenager, really likes to use social media which has various forms in it in terms of worldly things and puts aside da'wah content on social media that has been created by the da'wah content creators or the preachers. So, social media can play an active role in improving the quality of students' understanding of their religion, especially Islam through this da'wah content.

Da'wah comes from Arabic, namely, $d a^{\prime} a, y a d^{\prime} u, d a^{\prime} w a n, d u^{\prime} a$ which is interpreted as inviting or calling, calling, calling, requesting, and requesting (Toni Pransiska et al., 2013). Da'wah has the essence to grow one's tendencies and interests in calling on Islam. Calling for Islam here means as an effort to foster a tendency and interest in what is called for, namely Islam so that Islamic da'wah is not only limited in the dimensions of oral activity but also includes all oral activities or actions aimed at fostering a tendency and an interest in Islam.

Referring to the Qur'an and Al-Hadith as a guideline for Muslims, da'wah has, in fact, become an obligation, one of which is:

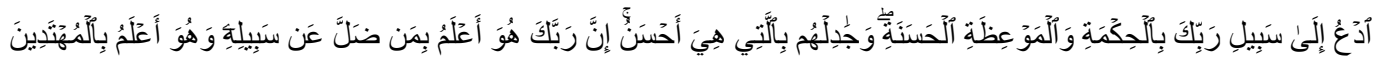

Meaning : "Invite to the way of your Lord with wisdom and good instruction, and argue with them in a way that is best. Indeed, your Lord is most knowing of who has strayed from His way, and He is most knowing of who is [rightly] guided". (QS. An-Nahl:125)

Whereas in a Aadith, the obligation to preach is by what has been narrated by Imam Tirmidhi: From Khudzaifah ra from the Prophet said; "By the One who controls me, you must invite to goodness and you must prevent evil deeds or Allah will send His punishment to you then you pray to Him where Allah will not grant your request" (Narrated by Imam Tirmidhi).

The duty of a Muslim is to preach (Putra, 2021). Da'wah is a necessity for everyone in particular Muslims in this world (Parhan et al., 2021). By understanding the basis of the obligation to preach, Islam can be known, better understood, and can be internalized in our daily lives. On the other hand, without a da'wah, understanding of the teachings of Islam will be cut off, as a religion that is kaffah (perfect) in its form. In addition, da'wah has a function to preserve Islamic values itself, straighten morals or crooked behaviour from the beginning. straight, and bring people out of spiritual darkness itself. Da'wah can be delivered in various ways and various media, one of which is social media (Sumadi \& Kudus, 2016). There is a component involved in da'wah, namely Da'i, namely people who deliver da'wah another term is mubaligh or 'tabligher' (Syarifudin, 2015).

So da'wah content is content, information, or messages conveyed by a preacher or Da'i using internet media or social media. The materials presented in the da'wah are diverse which certainly cannot be separated from the guidance of the Qur'an and Hadith as the main source of Islamic sharia which includes aqidah, morals, Sharia and various kinds of knowledge that exist and is obtained from them.

In addition to obligatory da'wah, students should also understand Islam in depth. Bloom in Anderson et al., 2001 claim that understanding is the ability to interpret or repeat information using our language. Comprehension is a cognitive aspect in Bloom's Taxonomy which is divided into 6 aspects, namely introduction, understanding, application, analysis, synthesis, and evaluation. To gain an understanding of information or material, there is a thought process. Thinking leads us to a stage to form an understanding, initiate an opinion, and conclude.

According to Anderson et al., 2001 suggest that “.... in the category of understanding includes seven cognitive processes, including interpreting (interpreting), giving examples (exemplifying), classifying 
(classifying), summarizing (summarizing), drawing inference / inferring (inferring), comparing (comparing), and explaining (explaining) ".

So, understanding Islam is a way, process, deed, or understanding in its entirety about Islam. This understanding means understanding in-depth about the teachings of Islam, implementing all the teachings that have been taught, and being able to explain in detail everything related to Islam.

Several other that related studies have been carried out regarding the influence of da'wah through social media. As has been done by Maujuhan Syah, 2020 claims that there was an influence from da'wah content. Then, Syariffudin \& Muhid, 2021 also conducted research and stated that social media is a effective media to spread out the da'wah. Furthermore, related research has also been carried out Sikumbang et al., 2020 about You tube can be a good media for da'wah. Besides, You Tube is a perfect media for the da'wah platform in this disruption area (Hilmi, 2021). Furthermore also conducted research about the development of da'wah through effective social media to use (Ramadhan R \& Destiana $\mathrm{H}, 2018$ ).

Of all the existing research, there is still no related research that discusses the relevance of da'wah content spread through social media to a deep understanding of the religion of Islam with a student. Many studies are still discussing the relationship of social media as a medium for spreading da'wah. In some studies, it is also still focused on the level of effectiveness of social media as a medium for us to preach and without any related parameters that encourage the effectiveness of social media as a medium for spreading da'wah.

This article or this research has another focus on the level of effectiveness or influence of da'wah content through social media regarding students' understanding of Islam itself. Related to this, previously there were also studies related to the parameters related to the influence of da'wah content delivered on social media on other aspects, for example, the level of student religiosity after seeing a da'wah content through social media.

Therefore, this research is intended to provide a more detailed picture of how the influence of da'wah content disseminated to the public, especially students, on the level of understanding of Islam. In addition, this study also aims to find out what things we can see in describing the level of understanding of the Islamic religion of students. From all the objectives of this research, it is expected to be able to provide a new insight that explains whether da'wah should be written or disseminated through social media or not.

The scientific benefits of this article are intended for ustadz, teachers, religious leaders, organizations engaged in the field of religion who often spread their da'wah through various ways or platforms. Through this paper, later preachers who want to spread their knowledge through da'wah with social media will understand better that social media is a platform that can be used as a reference for broadcasting their da'wah. There are also many other benefits related to this paper that can help other researchers as their literature studies in developing research related to the influence of social media which is used as a forum for disseminating da'wah to the level of understanding of Islam for its listeners.

\section{Methods}

This study uses a descriptive approach by using the independent variable, namely the content of da'wah through social media and the dependent variable, namely the understanding of Islam in students. In this study, questionnaires were used as material to spread questions related to the things to be studied. This study did not use samples in data collection because the subjects taken for this study were the entire population with the following characteristics:

1. Active students from several universities and polytechnics with a total of 90 people

2. The student is with an age range of 17-20 years

The use of the entire population of this study because the number of respondents who filled out the questionnaire in this study amounted to 90 people and less than 100 so that the entire population was taken in the process of data analysis. The method for collecting data used for this research is the level of understanding of the students about Islam. This level of understanding of Islam was given to several students who filled out research questionnaires with an age range of 17-20 years. This level of understanding of Islam is given to reveal the understanding of Islam from a student after they watch or listen to content containing da'wah from social media.

After filling out all the questionnaires by the respondents, data processing is carried out from the results of online questionnaire answers to get validation and suitability of the answers. After that, a data tabulation was carried out using a Likert scale with a scale of strongly disagree as a value of 1 to strongly 
agree as a value of 5. In addition, the assessment of the scale was also based on the level of positivity of the answers.

The research was conducted by conducting a validity test using Pearson's product-moment correlation, which was calculated using SPSS for Windows 26 software. Then proceeded to calculate the reliability to describe the extent to which the measurement results with this tool can be trusted or not. This is indicated by the level of constancy (consistency) of the scores obtained by each subject measured with the same instrument or device, or measured with an equivalent instrument under different conditions. In this reliability test, the approach is used for one measurement (Single Trial Administration) and is carried out by calculating Cronbach's Alpha which is calculated using SPSS for windows 26.

After all the validity and reliability tests have been carried out, data processing is carried out using the normality test with residual values and the one-sample Kolmogorov-Smirnov technique is used with SPSS for windows 26 software. This normality test itself is used to test whether, in a regression model, the dependent variable or the dependent variable, the independent variable or the independent variable has a normal distribution or not on both.

Then a simple linear regression analysis was carried out in this study which was equipped with the aim of measuring the strength of relationship and the influence of the relationship between the variables, as well as showing the direction of the relationship between the independent (independent) and dependent (dependent).

\section{Result and Discussion}

\subsection{Result}

\section{A. Validity Result Test}

Table 1 Instrument Validity Result Test Da'wah Content Trough Social Media (X Variable)

\begin{tabular}{|c|c|c|c|c|}
\hline No & Items (Questions) & $\begin{array}{c}\text { Corelation } \\
\text { Result }\end{array}$ & r Table 1\% & Conclusion \\
\hline 1 & $\mathrm{X} 1$ & 0.531 & 0.267 & Valid \\
\hline 2 & $\mathrm{X} 2$ & 0.299 & 0.267 & Valid \\
\hline 3 & $\mathrm{X} 3$ & 0.542 & 0.267 & Valid \\
\hline 4 & $\mathrm{X} 4$ & 0.388 & 0.267 & Valid \\
\hline 5 & $\mathrm{X} 5$ & 0.626 & 0.267 & Valid \\
\hline 6 & $\mathrm{X} 6$ & 0.600 & 0.267 & Valid \\
\hline 7 & $\mathrm{X} 7$ & 0.632 & 0.267 & Valid \\
\hline 8 & $\mathrm{X} 8$ & 0.714 & 0.267 & Valid \\
\hline 9 & X9 & 0.622 & 0.267 & Valid \\
\hline 10 & $\mathrm{X} 10$ & 0.504 & 0.267 & Valid \\
\hline 11 & $\mathrm{X} 11$ & 0.611 & 0.267 & Valid \\
\hline 12 & $\mathrm{X} 12$ & 0.497 & 0.267 & Valid \\
\hline
\end{tabular}


The table above shows that there is a correlation between all items (questions) and their total score ( $\mathrm{r}$ xy) and shows a result that is greater than the $r$ table value for $1 \%$. The item that has the highest correlation value with the total score is item number 8 with question X8 with a correlation value of 0.714 and is valid for a significance level of $1 \%$ which is worth 0.267 for the questionnaire value filled out by 90 people. Meanwhile, the value of the item that has the lowest correlation is item number 2 with question $\mathrm{X} 2$, which is with a correlation value of 0.299 and is valid because it exceeds the $1 \%$ significance level which is worth 0.267 for the value of the questionnaire filled out by 90 people. Meanwhile, the results of the instrument validity test for the Y variable or Islamic understanding can be seen in the following table:

Table 2 Instrument Validity Result Test Islamic Understanding (Y Variable)

\begin{tabular}{lcccc}
\hline No & Items (Questions) & $\begin{array}{c}\text { Corelation } \\
\text { Result }\end{array}$ & r Table 1\% & Conclusion \\
\hline 1 & X1 & 0.647 & 0.267 & Valid \\
2 & X2 & 0.378 & 0.267 & Valid \\
3 & X3 & 0.664 & 0.267 & Valid \\
4 & X4 & 0.321 & 0.267 & Valid \\
5 & X5 & 0.659 & 0.267 & Valid \\
6 & X6 & 0.553 & 0.267 & Valid \\
7 & $\mathrm{X} 7$ & 0.430 & 0.267 & Valid \\
8 & $\mathrm{X} 8$ & 0.315 & 0.267 & Valid \\
11 & $\mathrm{X}$ & 0.618 & 0.267 & Valid \\
\hline 9 & $\mathrm{X} 9$ & 0.692 & 0.267 & \\
\hline
\end{tabular}

The table above shows that there is a correlation between all items (questions) and their total score ( $\mathrm{r}$ xy) and shows a result that is greater than the $r$ table value for $1 \%$. The item that has the highest correlation value with the total score is item number 11 with question X11 with a correlation value of 0.780 and is valid for a $1 \%$ significance level which is worth 0.267 because it is more than that value for the questionnaire value filled out by 90 people. Meanwhile, the value of the item that has the lowest correlation is item number 8 with question $\mathrm{X} 8$, which is with a correlation value of 0.315 and is valid because it exceeds the $1 \%$ significance level which is worth 0.267 for the value of the questionnaire filled out by 90 people. 


\section{B. Reliability Result Test}

Table 3 Instrument Validity Result Test Da'wah Content Trough Social Media (X Variable) Reliabilty Statistics

\begin{tabular}{cc}
\hline Cronbach' Alpha & N of items \\
\hline .750 & 13
\end{tabular}

The results of the reliability test in table 3 above show that Cronbach's alpha is quite large, namely 0.750 , and it means that the value is above 0.60 , so it can be concluded that all items measuring the $\mathrm{X}$ variable from the questionnaire are reliable. The reliability of the $Y$ variable can be seen in the following table:

Table 4 Instrument Validity Result Test

Islamic Understanding (Y Variable) Reliabilty Statistics

\begin{tabular}{cc}
\hline Cronbach' Alpha & N of items \\
\hline .770 & 11
\end{tabular}

The results of the reliability test in table 4 above show that Cronbach's alpha is quite large, namely 0.770 , and it means that the value is above 0.60 , so it can be concluded that all items measuring the $\mathrm{Y}$ variable from the questionnaire are reliable.

\section{Normality Result Test}

Table 5 Normality Data Result Test

One-Sample Kolmogorov-Smirnov Test

\begin{tabular}{lll}
\hline & & $\begin{array}{l}\text { Unstandarized } \\
\text { Residual }\end{array}$ \\
\hline $\mathrm{N}$ & & 90 \\
Normal Parameters & & \\
& Mean & .0000000 \\
Most Extreme Differences & Std. Deviation & 2.87155460 \\
& Absolute & .075 \\
& Positive & .061 \\
Test Statistic & Negative & -.075 \\
Asymp. Sig. (2-tailed) & & .075 \\
& & $.200^{\mathrm{c}, \mathrm{d}}$ \\
\hline
\end{tabular}

\footnotetext{
a. Test distribution is Normal.

b. Calculated from data.

c. Lilliefors Significanca Correction

d. This is a lower bound of the true significance
}

The results of the reliability test in table 4 above show that Cronbach's alpha is quite large, namely 0.770 , and it means that the value is above 0.60 , so it can be concluded that all items measuring the $Y$ variable from the questionnaire are reliable. 


\section{Simple Regression Analysis Result Test}

Table 6 Simple Regression Analysis Result Test Coefficients ${ }^{\mathrm{a}}$

\begin{tabular}{ccccccc}
\hline & & \multicolumn{5}{c}{ Standarized } \\
Model & & Unstandarized & Coefficients & Coefficients & & \\
\hline \multirow{2}{*}{1} & $\mathrm{~B}$ & Std. Error & Beta & $\mathrm{t}$ & Sig. \\
\hline & (Constant) & .372 & 3.303 & & .113 & .911 \\
& Da'wah Content Trough & .831 & .060 & .829 & 13.929 & .000 \\
& Media Social & & & & & \\
\hline
\end{tabular}

a. Dependent Variable : Islamic Understanding

$\mathrm{Y}=0.372+0.831 \mathrm{X}$

From the table above, it can be explained that the significant value of 0.000 is smaller than 0.05 so that it can be concluded that the regression coefficient is significant and the regression equation model: Understanding Islam $=0.372$ means that if the Content of Da'wah Through Social Media is 0.911, then the effect on understanding Islam is positive, which is 0.372 and the variable of Da'wah Content Through Social Media has an effect of 0.831 .

\section{E. Coefficient Correlation Result Test}

Table 7 Correlation Coefficient Calculation Results (r) Model Summary

\begin{tabular}{|c|c|c|c|c|}
\hline Model & $\mathrm{R}$ & R Square & $\begin{array}{l}\text { Adjusted } \\
\text { Square }\end{array}$ & $\begin{array}{l}\text { Std. Error of the } \\
\text { Estimate }\end{array}$ \\
\hline $\begin{array}{ll}1 & .829 a\end{array}$ & & .688 & .684 & 2.888 \\
\hline
\end{tabular}

The table above illustrates that the value of $r$ or the correlation coefficient is $=0.829$, this shows that the relationship between all independent variables and the dependent variable is very high.

\section{F. Coefficient Determination Result Test}

Table 8 Determination Coefficient Calculation Results $\left(\mathrm{r}^{2}\right)$ Model Summary

\begin{tabular}{lllll} 
Model & R & R Square & $\begin{array}{l}\text { Adjusted } \\
\text { Square }\end{array}$ & $\begin{array}{l}\text { Std. Error of the } \\
\text { Estimate }\end{array}$ \\
\hline 1 & .829 a & .688 & .684 & 2.888 \\
\hline & \multicolumn{4}{l}{} \\
\hline a. & Predictors: (Constant), Da'wah Content Trough Social Media
\end{tabular}

The results of the coefficient of determination test (R2) obtained 0.688 . This means that $68.8 \%$ of students' understanding of Islam is influenced by the variable of Da'wah Content Through Social Media, while the remaining $31.2 \%$ is influenced by other variables that are not included in the focus of this research. 


\section{G. Model Feasibility Result Test}

Table 9 Model Feasibility Test Calculation Results (F Test) ANOVAa

\begin{tabular}{lllllll}
\hline \multicolumn{1}{c}{ Model } & $\begin{array}{l}\text { Sum of } \\
\text { Square }\end{array}$ & Df & $\begin{array}{l}\text { Mean } \\
\text { Square }\end{array}$ & F & Sig. \\
\hline 1 & Regression & 1617.910 & 1 & 1617.910 & 194.005 & $.000^{\mathrm{b}}$ \\
& Residual & 733.878 & 88 & 8.430 & & \\
& Total & 2351.789 & 89 & & & \\
\hline
\end{tabular}

a. Dependent Variable: Islamic Understanding

b. Predictors: (Constant), Da'wah Content Trough Social Media

From the results of the model feasibility test ( $\mathrm{f}$ test) in the table above, we can see that a simple linear regression model can be used to predict Islamic understanding which is influenced by da'wah content through social media. This can be proven from the calculated F value of 194,0005 with a significance value (sig) of .000 . Because the significance value does not exceed 0.05 , the simple linear regression model can be used to predict a student's understanding of Islam which is influenced by da'wah content through social media.

\subsection{Discussion}

The results of the analysis that have been carried out using SPSS for Windows 26 software, show that there is an influence between broadcasting a da'wah content through social media on the understanding of Islam for students aged 17-20 years. This research proves something new that has not existed in previous studies. However, there may be equivalent studies that have discussed the effect of da'wah content disseminated through social media on other cognitive aspects as was done Rizal et al., 2019 which explained in his research that the religious behaviour of MAN 2 Palembang students shows moderate or good results after seeing YouTube social media da'wah. In another study, it was explained that there was indeed an influence, there was an influence from da'wah content that was disseminated through YouTube social media on the level of religiosity of Al-Muhtadi Sendangagung students as was done (Maujuhan Syah, 2020).

An understanding of Islam is a process, a way, an act to understand everything that comes from Islam. This understanding of Islam describes a religious depth that emerges from a person which is reflected in both his knowledge and his actions so that it encourages that person to do and implement all the things he knows and has been taught in the teachings of Islam. Every human being himself has a different level of understanding depending on each human being in understanding the teachings of Islam and is caused by several factors in the human being in implementing his understanding. These factors can be in the form of being able to explain what he knows, interpret it, give examples, draw conclusions, and compare. These factors are also influenced by external factors which can also be in the form of words and actions that are exemplified by other people who are considered qualified and can be imitated as well as preachers, ustadz, religious leaders. This is also the case when they see it on social media, the giving of da'wah given by millennial preachers on social media gives an interest in itself to students so that an understanding emerges regarding what they have learned about Islam in the da'wah content.

Changing delivery concept dakwah through the digitalization model indeed it's not easy and also it's not easy to understand by public. Dakwah can be done in a different way than before or it can be said that da'wah can be done a renewal by doing it on various social networks such as YouTube, Facebook, Twitter, Instagram, and others. Therefore, technological prowess in the current era has an impact on the provision of da'wah which will also develop later. Da'i here get a new challenge in the process of preaching to better keep up with the times. Da'i is expected to be able to make good use of this social networking site as one of the modern da'wah platforms that have other benefits with the process of disseminating information from the contents of the da'wah content to be spread outward and faster in various age groups. In the end, the social networking site will not only contain films and entertainment but can be used as an effective means of disseminating da'wah about Islam.

The results of this study, although they do not explain other influences for a student after seeing da'wah content through social media, but are sufficient to provide one of the factors that can be obtained 
from a student after he sees da'wah content through social media, namely his understanding (according to table 8) of $68.8 \%$. After conducting further cross-checks, there are still many limitations of this study, especially in the small sample so that the data analyzed is also still less varied. So, in future research, it is recommended to look for more samples so that more varied and more accurate results occur later.

Many students do not use their social media as a place to watch da'wah content. Many students also understand Islam through the learning process at school. He got this understanding from his teachers or other religious leaders. Therefore, the learning process of these students becomes a direct process that makes these students understand Islam and social media here becomes a medium that strengthens their understanding.

\section{Conclusions}

This study aims to determine the effect of da'wah content through social media on the understanding of Islam by a student with an age range of 17-20 years. From the introduction that has been described, the data analysis that has been carried out and the discussion that has been stated in the previous section, it can be drawn some conclusions which are listed as follows:

1. Based on the results of the analysis and discussion that has been carried out in the previous section, it can be concluded that the respondents of this study were students with a total of 90 people, with 13 people aged 17 years, 48 people aged 18 years, 24 people aged 19 years, and the remaining 5 people aged 20 years.

2. The results of the simple linear regression test are the significance value of 0.000 which is smaller than 0.05 so it can be concluded that the regression coefficient is significant and the simple linear regression equation $\mathrm{Y}=0.372+0.831 \mathrm{X}$. The regression coefficient of 0.372 explains that if the content of da'wah through social media is 0.911 then one's understanding of Islam students of 0.372 .

3. From the results of the model feasibility test ( $F$ test) shows the calculated $F$ value of 194,0005 $>\mathrm{F}$ table 9 with a significance value (sig) of 0.000 . Because the value of the significance is less than 0.05 , this simple linear regression model can be used to predict the Islamic understanding of a student aged 17-20 years who is influenced by the content of da'wah through social media. So, it can be concluded that the content of da'wah through social media has an influence that increases the understanding of the Islamic religion of a student aged 1720 years.

Acknowledgments We thank Imamul Arifin, Lc, M.HI. to assist in conducting and funding this research. We also thank all respondents who are willing to be the object of this research. And we also don't forget to thank our parents who always support us.

\section{References}

Alamsyah A. (2018). EFEKTIVITAS DAKWAH MELALUI MAJALAH. Jurnalisa : Jurnal Jurusan Jurnalistik, 4(1), 106-120. https://doi.org/https://doi.org/10.24252/jurnalisa.v4i1.5624

Anderson, L. W., Bloom, B. S., Krathwohl, D. R., Airasian, P., Cruikshank, K., Mayer, R., Pintrich, P., Raths, J., \& Wittrock, M. (2001). A Taxonomy for Learning, Teaching, and Assessing: A Revision of Bloom's Taxonomy of Educational Objectives. Longman. https://books.google.co.id/books?id=EMQlAQAAIAAJ

Cahyono A. (2016). PENGARUH MEDIA SOSIAL TERHADAP PERUBAHAN SOSIAL MASYARAKAT DI INDONESIA. Jurnal Publicana, 9(1), 140-157.

https://journal.unita.ac.id/index.php/publiciana/article/view/79

Hilmi, M. (2021). Youtube as Da'wah Media Innovation in Disruption Era. MUHARRIK: Jurnal Dakwah Dan Sosial, 4(01), 21-31.

Maujuhan Syah, A. (2020). Pengaruh Dakwah Media Sosial Youtube terhadap Religiusitas Remaja di MA. Al-Muhtadi Sendangagung. Jurnal Komunikasi Dan Penyiaran Islam, INSUD. Busyro, 1(2), 20-36. 
Nikmah F. (2020). DIGITALISASI DAN TANTANGAN DAKWAH DI ERA MILENIAL. Musarah: Jurnal Kajian Islam Kontemporer, 2(1), 42-52. https://doi.org/https://doi.org/10.18592/ muảșarah.v17i1.3002

Parhan, M., Khairulimam, A., Nurfitriyani, M., Nabila Ababil, S., \& Pembangunan Nasional Veteran Jakarta, U. (2021). Dakwah di masa pandemi Covid-19: Eksistensi, problematika serta solusi. Jurnal Ilmu Dakwah, 41(1), 85-96.

Putra, A. S. (2021). PERAN SOSIAL MEDIA SEBAGAI MEDIA DAKWAH DI MASA PANDEMI VIRUS CORONA (COVID-19) DI INDONESIA. PANANGKARAN, Jurnal Penelitian Agama Dan Masyarakat, 4(1), 89-97. https://doi.org/https://doi.org/10.14421/panangkaran.2020.\%x

Ramadhan R, \& Destiana H. (2018). Pengaruh Media Sosial Youtube Terhadap Perkembangan Dakwah Islam Dengan Metode Structural Equation Modeling(SEM). Jurnal \& Penelitian Teknik Informatika, 1(3), 60-66. https://jurnal.polgan.ac.id/index.php/sinkron/article/view/150

Rizal, S., Syarifuddin, A., \& Syarnubi, D. (2019). PENGARUH AKUN DAKWAH YOUTUBE TERHADAP PERILAKU RELIGIUSITAS SISWA DI MAN 2 PALEMBANG. 351(3), 351-370. http://jurnal.radenfatah.ac.id/index.php/pairf

Sikumbang, A. T., Fitra, R., \& Siahaan, U. (2020). YOUTUBE AS A DA'WAH MEDIA. Jurnal Al-Bayan: Media Kajian Dan Pengembangan Ilmu Dakwah, 26(2), 304-322. https://doi.org/10.22373/albayan

Sumadi, E., \& Kudus, S. (2016). DAKWAH DAN MEDIA SOSIAL: Menebar Kebaikan Tanpa Diskrimasi. ATTabsyir: Jurnal Komunikasi Penyiaran Islam, 4(1), 173-190.

Syariffudin, \& Muhid, A. (2021). Efektifitas Pesan Dakwah di Media Sosial Terhadap Religiusitas Masyarakat Muslim Analisis Literature Review. Jurnal Ilmu Dakwah, 20(1), 17-28. https://doi.org/http://dx.doi.org/10.18592/alhadharah.v20i1.4835

Syarifudin, A. (2015). FACEBOOK SEBAGAI MEDIA DAKWAH ISLAM. Wardah, 15(1), 67-77. https://doi.org/https://doi.org/https://doi.org/10.19109/wardah.v15i1.207

Toni Pransiska, S. P. I., Sabilla, M. R., S, I. A., H, I., Prasetyo, T., Fenova, T. S., \& Tera, I. (2013). Kamus Arab Indonesia - Indonesia - Arab Edisi Praktis. IndonesiaTera. https://books.google.co.id/books?id=cQV6CgAAQBAJ 